BRIEF REPORT

\title{
The fast and the fatal: street racing fatal crashes in the United States
}

\author{
S Knight, L J Cook, L M Olson
}

Injury Prevention 2004;10:53-55. doi: 10.1136/ip.2003.003566

See end of article for authors' affiliations

......................

Correspondence to: Stacey Knight, 615

Arapeen Drive, Suite 202,

Salt Lake City, Utah

84108, USA;

Stacey.Knight@hsc.utah.

edu

....................

\begin{abstract}
The objective of this study was to determine the annual incidence of fatal motor vehicle crashes involving street racing and to describe the characteristics of these crashes compared to other fatal crashes in the United States. The National Highway Traffic Safety Administration Fatality Analysis Reporting System data for 1998-2001 were used for the analyses. There were 149568 fatal crashes and $315(0.21 \%)$ involved street racing and 399 fatalities occurred in these crashes. In contrast to other fatal crashes, street racing fatal crashes were more likely to occur on urban roadways and were nearly six times more likely to occur at travel speeds $\geqslant 65 \mathrm{mph}$. Compared with other drivers involved in fatal crashes, street racers were more likely to be teenagers, male, and have previous crashes and driving violations. Street racing involves risky driving behaviors and warrants further attention.
\end{abstract}

E ach year there are approximately 37000 fatal motor vehicle crashes in the United States. ${ }^{1}$ Speeding is a contributing factor in almost a third of these crashes. ${ }^{2}$ As the travel speed of a vehicle increases so does the risk for a crash as well as the risk of a fatality. ${ }^{3}$ Therefore, the recent gain in popularity of street racing in movies, media coverage, video games, and websites is concerning. Street racing can range from spontaneous racing with another car to illegally organized events with spectators and marked distances on public roadways. In a study by Arnett and colleagues, 59\% of high school boys and $36 \%$ of high school girls reported they had raced another car in the past year. ${ }^{5}$ However, to our knowledge there is no literature on crashes that involve street racing. The purpose of this study is to determine the annual incidence of street racing involved fatal motor vehicle crashes and to describe the characteristics of these crashes and drivers compared to other fatal crashes and drivers in the United States.

\section{METHODS}

The National Highway Traffic Safety Administration (NHTSA) Fatality Analysis Reporting System (FARS) data for the years 1998-2001 were used for this study (http:// www-fars.nhtsa.dot.gov). The FARS database was established by NHTSA in 1975 in order to identify traffic safety problems and evaluate motor vehicle improvements and highway safety initiatives. This database contains information on all fatal crashes that occurred in the 50 states in the United States, the District of Columbia, and Puerto Rico. To be included in the FARS database, the crash must occur on a public roadway and result in at least one death to an occupant of a vehicle or non-motorist within 30 days of the crash. Over 100 standardized data elements that characterize the persons, drivers, and vehicles involved as well as the crash events are collected in FARS. The information for each fatal crash is gathered, translated, and transmitted by trained employee(s) (called "FARS analysts"). FARS data are obtained solely by reviewing documents including police accident reports, death certificates, state vehicle registration files, coroner/medical examiner reports, state driver licensing files, hospital medical reports, state highway department data, emergency medical service reports, Vital Statistics, and other state records in each state. Data are automatically checked for acceptable range values and for consistency when first entered, enabling the analyst to make immediate corrections. NHTSA personnel are continually monitoring the completeness and accuracy of the data.

Based on the review by the FARS analysts of the above mentioned documents (for example, police accident reports) up to four different driver factors can be coded. These factors include but are not limited to, fatigue, speeding, following improperly, and improper lane changes. Racing was added as a driver factor in 1998. A code of racing in any of the four reported driver factors in the FARS database was used to determine street racing involvement in this study. A crash was defined as being on an urban or rural roadway based on the Federal Highway Administration definition of urban or rural. Prior crashes, convictions for speeding, driving under the influence of alcohol or other drugs, and license revocation/suspensions occurring within three years of the date of the crash are reported in FARS and were used in this study. A teenage driver was defined as drivers aged 15 to 19 years old. In FARS, a driver was reported as being impaired at the time of the crash if the blood alcohol concentration is positive, or if the police reported alcohol involvement.

Crude odds ratios (OR) and $95 \%$ confidence intervals (CI) are reported; $\chi^{2}$ tests were used to test for associations. Since only fatal crashes are reported in FARS, no analysis examining the association between crash characteristics (including street racing) and crash outcomes could be conducted. SAS 8.2 (SAS Institute, Cary, NC) was used for the analysis. The University of Utah School Of Medicine Institutional Review Board approved this study.

\section{RESULTS}

There were 149451 fatal crashes reported in FARS for 19982001. Of these fatal crashes, $315(0.21 \%)$ involved street racing and street racing was a factor reported in 399 motor vehicle crash fatalities. Of the 399 fatalities, 299 (74.9\%) were either the driver or passenger in the street racing vehicle. The yearly number of street racing fatal crashes was $59(0.16 \%)$ in $1998,78(0.21 \%)$ in $1999,62(0.17 \%)$ in 2000 , and $116(0.31 \%)$

\footnotetext{
Abbreviations: $\mathrm{Cl}$, confidence interval; FARS, Fatality Analysis Reporting System; NHTSA, National Highway Traffic Safety Administration; $O R$, odds ratio
} 
Table 1 Crash characteristic of street racing $(n=315)$ and other fatal crashes $(n=149$ 136); United States, 1998-2001

\begin{tabular}{llll}
\hline Crash characteristics & $\begin{array}{l}\text { No }(\%) \text { street } \\
\text { racing fatal } \\
\text { crashes }\end{array}$ & $\begin{array}{l}\text { No }(\%) \text { other fatal } \\
\text { crashes }\end{array}$ & $\begin{array}{l}\text { OR }(95 \% \mathrm{Cl}) \text { of street racing } \boldsymbol{v} \text { other } \\
\text { fatal crashes }\end{array}$ \\
\hline Urban roadway & $236(76.6)$ & $58386(40.1)$ & $4.9(3.8$ to 6.4$)$ \\
Fixed object struck & $134(42.5)$ & $44297(29.7)$ & $1.8(1.4$ to 2.2) \\
Speed limit 65+ mph & $22(7.0)$ & $22542(16.5)$ & $0.4(0.2$ to 0.6) \\
Travel speed 65+ mph & $128(40.6)$ & $22495(15.1)$ & $5.6(4.4$ to 7.3$)$ \\
\hline
\end{tabular}

in 2001. In 2001 there was an increase of nearly 50 fatal crashes that involved street racing compared with the average of the previous three years.

Street racing fatal crashes occurred most often in the late evening and early morning hours, while other fatal crashes were more evenly distributed throughout the day $(\mathrm{p}<0.001)$. The days of the week the crashes occurred were similar for the street racing and other fatal crashes $(p=0.34)$. Crash characteristics of street racing fatal crashes are compared to other fatal crashes in table 1. Street racing fatal crashes were nearly five times more likely to have occurred on an urban roadway compared with other fatal crashes (95\% CI 3.8 to 6.4). While street racing fatal crashes were less likely than other fatal crashes to be on roadways with a speed limit greater than $65 \mathrm{mph}$, they were nearly six times more likely to occur at travel speeds greater than $65 \mathrm{mph}$ (95\% CI 4.4 to 7.3).

The characteristics of street racing drivers and other drivers involved in fatal crashes are compared in table 2 . Street racers were more likely to be a teenager (OR 4.6 ; $95 \%$ CI 3.7 to 5.7 ) and male (OR $4.5 ; 95 \%$ CI 3.0 to 6.6 ) than other drivers involved in fatal crashes. Compared with other drivers involved in fatal crashes, street racers were more likely to have previous crashes and driving violations as well as be impaired at the time of the crash (table 2). Among the drivers that survived the fatal crash, street racers were six times more likely to be charged with manslaughter than the other drivers (95\% CI 4.6 to 8.8 ).

\section{DISCUSSION}

Our study of street racing fatal crashes has three main findings. First, street racing was a factor in a small percentage of fatal crashes. Secondly, street racing fatal crashes not only involved excessive speeds but also often involved alcohol and occurred on urban surface streets (that is, urban non-interstate or non-freeway roadways). Third, street racers tended to be male teenagers with poor driving histories. These findings may help with the identification of target populations and the development of intervention programs.
When considering that risky behaviors such as driving while impaired were reported in over $40 \%$ of all fatal crashes and speeding in general was reported in approximately $30 \%$, street racing, which was reported in fewer than $1 \%$ of fatal crashes, is an extremely rare factor in fatal crashes. However, since our analyses were only of fatal crashes, we were unable to determine if street racing increased the risk of a fatal crash compared to driving while impaired or speeding in general. Considering that we found that street racing fatal crashes often involved both excessive speeds and alcohol and both of these driving behaviors have been linked to an increased risk of a crash and a fatality, ${ }^{36}$ it might stand to reason that street racing may also be associated with an increased risk of a crash and fatality. Therefore, further research is warranted to determine if street racing is risky behavior even after controlling for other confounding factors such as speeding and impaired driving.

Street racing often occurs on urban surface streets that are not designed for the street racing speeds. The urban roads often have increased traffic flow, and fixed objects such as street lights that may add to the risk of a fatality during a street racing event. Raceways have been promoted as safe alternatives to street racing. Most raceways allow amateur racers that meet the minimum safety requirement such as those set forth by the National Hot Rod Association Rulebook. ${ }^{7}$ However, the effectiveness of raceways at reducing street racing has not been evaluated.

Most states have laws against street racing that result in a fine, license suspension, or jail time for the street racer. ${ }^{8}$ It may be necessary to evaluate these laws and ascertain if increasing penalties for street racing is needed. Throughout the United States several state and local laws have recently been implemented or proposed that either increase the penalties for street racing or address illegal street racing exhibitions. These include the seizure of vehicles involved in street racing, the misdemeanor citation of spectators that are present at illegal street racing events, and the designating of "no racing zones". While these may be successful, evaluation of these laws is needed.

Since drivers involved in street racing tended to be teenage male drivers with poor driving histories, targeting this

Table 2 Driver characteristic of street racer $(n=371)$ and other drivers $(n=227,305)$ involved in fatal crashes; United States, 1998-2001

\begin{tabular}{|c|c|c|c|}
\hline Driver characteristics & $\begin{array}{l}\text { No }(\%) \text { street } \\
\text { racers }\end{array}$ & No $(\%)$ other drivers & $\begin{array}{l}\text { OR }(95 \% \mathrm{Cl}) \text { street racer } v \\
\text { other drivers }\end{array}$ \\
\hline Teenager (15-19 years) & $134(36.1)$ & $25659(11.3)$ & 4.6 (3.7 to 5.7$)$ \\
\hline Male & $335(90.3)$ & $164611(72.4)$ & $4.5(3.0$ to 6.6$)$ \\
\hline Previous crash & $72(19.4)$ & $32941(14.4)$ & $1.5(1.1$ to 1.9$)$ \\
\hline Previous license suspension & $67(18.1)$ & $27323(12.0)$ & $1.6(1.2$ to 2.1$)$ \\
\hline Previous speeding violation & $105(28.3)$ & $46819(20.5)$ & $1.5(1.2$ to 1.9$)$ \\
\hline Previous DW|* violation & $18(4.9)$ & $7465(3.3)$ & $1.5(0.9$ to 2.4$)$ \\
\hline Positive $\mathrm{BAC} \dagger$ at time of crash & $117(31.5)$ & $45985(20.1)$ & $1.8(1.5$ to 2.3$)$ \\
\hline
\end{tabular}

*Driving while impaired with alcohol or other drugs.

†Blood alcohol concentration. 


\section{Key points}

- A small percentage of fatal motor vehicle crashes involve street racing.

- Street racers involved in fatal crashes tended to be male teenagers with poor driving histories.

- Street racing fatal crashes were nearly six times more likely than other fatal crashes to occur at travel speeds greater than $65 \mathrm{mph}$.

- Street racing fatal crashes often involved impaired driving.

- Further research including the need for education campaigns, intervention programs, and legislative efforts addressing street racing and associated risky driving behaviors warrants consideration.

population may provide the most promise for an intervention program. Courses targeting novice drivers (for example, driver's education classes in the United States) may be a place for an education campaign about street racing and its negative consequences. Additionally, street racing could be included in graduated licensing programs by introducing street racing provisions that would revoke the license of teenagers convicted of street racing similar to the provision in graduated licensing programs for drinking and driving.

There are some limitations with this study. First, we studied only fatal crashes, and therefore, we were unable look at street racing or street racers in general. Thus, these results are probably not generalizable to all street racers but may represent an important subpopulation at greatest risk for a fatal crash. This also does not allow us to examine the risk of a fatal crash in terms of street racing while controlling for other factors. We also lacked information about the chain of events preceding the crash. For example, we were unable to determine whether these street races were organized events with spectators or spontaneous events. Further detail about these crashes may help with the development of prevention programs.

Despite these limitations, we have shown that while street racing is a factor in a small number fatal crashes in the
United States, street racing fatal crashes often involve risky driving behaviors such as speeding and impaired driving compared with other fatal crashes. As such, street racing can result in devastating consequences, including lives lost and serious criminal charges, especially for teenaged drivers. Further research, including the need for education campaigns, intervention programs, and legislative efforts addressing street racing and associated risky driving behaviors warrants consideration.

\section{ACKNOWLEDGEMENTS}

This work was partially funded by National Highway Traffic Safety Administration, cooperative agreement number DTNH22-00-H67012.

This work was partially presented at the American Public Health Association Meeting; November, 2002; Philadelphia, PA.

\section{Authors' affiliations}

S Knight, L J Cook, Intermountain Injury Control Research Center, Department of Pediatrics, University of Utah School of Medicine, Salt Lake City, Utah

L M Olson, Intermountain Injury Control Research Center and Department of Pediatrics, Division of Critical Care, Primary Children's Medical Center, University of Utah School of Medicine, Salt Lake City, Utah

\section{REFERENCES}

1 National Highway Traffic Safety Administration. Traffic safety facts 2000. Washington, DC: NHTSA, 2001.

2 National Highway Traffic Safety Administration. Traffic safety facts 2000: speeding. Washington, DC: NHTSA, 2001.

3 Kloeden CN, McLean JJ, Moore VM, et al. Traveling speed and the risk of crash involvement. Canberra, Australia: Federal Office of Road Safety, 1997.

4 Joksch HC. Velocity change and fatality risk in a crash-a rule of thumb. Accid Anal Prev 1993;25: 103-4.

5 Arnett JJ, Offer D, Fine MA. Reckless driving in adolescence: "state" and "trait" factors. Accid Anal Prev 1997;29:57-63.

6 Levitt S, Porter J. Estimating the effect of alcohol on driver risk using only fatal accident statistics. Cambridge, MA: National Bureau of Economic Research, 1999.

7 National Hot Rod Association. 2003 National Hot Rod Association rulebook. Glendora CA: National Hot Rod Association, 2003.

8 National Highway Traffic Safety Administration. Summary of state speed laws. 5th Ed: current as of 1 January 2001. Washington, DC: NHTSA,
2001 . 